\title{
Benchmarking Practices through Online Social Networking
}

\author{
A. W. Norailis and Y. Nor Asiah
}

\begin{abstract}
Benchmarking of online social network is a tool for continuous improvement in an organizational setting. This study examines the underline practice of online social network in benchmarking the practice in small and medium scale enterprises in Malaysia. The study employed qualitative approach by interviewing small and medium enterprise owners. The result indicate there are changes in performance by adopting benchmarking for service delivery that result from using new medium. It also implied that benchmarking approach can lead to new innovation through the exchange of information in a secured business environment with a significant effect on the financial well-being of the business. The regulators are most significant in benchmarking to reduce the competitive behavior among the business of the same character. The limitation of this study is small sample size. Therefore, future study can be conducted using survey method and also by increasing the sample size.
\end{abstract}

Index Terms-Benchmarking, online social networking, small and medium enterprises.

\section{INTRODUCTION}

Small and medium enterprises (SMEs) around the globe are major economic engines that stimulate economic growth of nations [1]. There are nearly ninety million SMEs in emerging markets around the globe [2]. Hence, the extension of forthcoming competitors and the shape of competition in offering outputs have created opportunities for infinite creativity in a borderless world. There are several countries appeared to focus on connectivity metrics rather than the usage metrics [3]. This is because they are seen as the keys to the knowledge-based economy with the assurance of having competitive advantage towards the future economy economies [1].

The SME Corporation of Malaysia (SME Corp) found more than 50\% SMEs believed their performance will continue to grow with the support of product demands in the country and the increasing rate of tourism activities as well as exports [4]. The agency expected the Gross Domestic Product (GDP) to increase from 32 percent to 41 percent in the present year. However, the Malaysian government take an actions in the 2014 Budget contribute and create a conducive environment entrepreneur to achieve their objectives in term of business number and productivity [5]. Among the effort by the government was the budget of RM 120 million announced by the government to increase innovation and productivity of the SMEs in Malaysia. The

Manuscript received February 14, 2014; revised April 5, 2014.

The authors are with the Faculty of Economics and Muamalat, Universiti Sains Islam Malaysia, 71800 Nilai, Negeri Sembilan, Malaysia (e-mail: norailis@usim.edu.my, norasiah@usim.edu.my). remaining parts of this study are presented as background of benchmarking and online social network, methodology, results, discussion and conclusion.

\section{LITERATURE REVIEW}

\section{A. Benchmarking Practice}

Benchmarking is a tool for continuous improvement in an organizational settings [6]. the importance of understanding "benchmarking" and its effects on businesses [7]. However, [8]-[10] comprehends the function of benchmarking guarantees that knowledge is gained across areas. The application of benchmarking process in organization has effect on the sustainability in the business arena [11]. In addition, [12] emphasized on the different structures with formal and informal benchmarking exercises.

It is necessary to benchmark global industry standards including a look into the best practices at the team, work-group, and organizational level [13]-[15]. More so, [16] draw attention of the entrepreneur to by using holistic approach to organizational comparison instead of focusing on particular parts in an organization. Furthermore, [17] highlighted that respective organizations should put emphasis on different approaches to benchmarking depending upon regulatory context and company strategy.

The discrepancies in the area with the widest maturity and practices that are closely related to talents which include human resource development and management, quality and operational results as well as customer focus and satisfaction[18]. In fact, [19] stressed on the need to increase awareness on the importance of human resource in organizations. In addition, the role of human resource was the most influential factor on benchmarking adoption by the top management commitment [15], [20], [21]. There is high level of influence by the management in managing people with unique knowledge and skills [22].

On the opinion by [12], [23], [24] the reasons for less practice in benchmarking which include it comparison with other techniques, mediums, unclear obstacles on its adoption and lack of empirical data on the reception of different types of benchmarking. In fact, [25] opined similarly, and added that the practice could affect the competitive rivalry.

\section{B. Online Social Networking}

Online social networking is a platform to build relations among owners or managers in the contest of this study. The different virtual communities in online social networking $(\mathrm{OSN})$ which are frequently updated with new information technologies[26]. This medium is utilized as the intention of sharing their knowledge, experiences and mutual interests to 
the organization [27].

Furthermore, it is expected that businesses deal with customers that are facilitate with internet connections and mobile telephones through microcomputer sales [3]. These mediums are best for the deals to promote the company's brands [27]. OSN presents many potential significant benefits as well as risks too [28].

In contrast, to the informal evidence showed that the uptake of e-applications by businesses is low [3]. Given the reason that SMEs are hardly applied in e-business which has gone beyond email and Web sites in increasing numbers of ICT applications [1]. These businesses realized that investments have to be made in those areas since the technologies allow greater returns that have greater chances of reacting to real business needs [29].

Realizing the importance of SMEs to the nation, it is best if their opinion has been highlighted by the researcher. The objective of this study is to examine the perception and expectations of benchmaking practices through a substantial media in exploring and comparing the issues related to SMEs in Malaysia.

\section{Methodology}

A qualitative method of analysis was employed to provide in-depth information for this study. Thus, the information was gathered through sessions of interviews with business owners in halal food industry. The profile of the respondents shows an average duration of thirteen years in the manufacturing industry.

The hour used in interviewing lasted for an average of one hour in their business premises. A recorder was used to facilitate the interviews as well as comprehensive notes of the answers. The results of each interview were transcribed after each session. Further analysis using NVivo software to crystalize the data with the aim of identifying and classifying feedbacks regarding the objective of the study.

\section{RESUltS AND DisCUSSION}

The results of interviews and its discussion were elaborated from the responses of interviewees' statements related to their experiences in handling businesses using OSN.

Hence, the key drivers of benchmarking practices from the interview were the managers and the business owners. The justification for these is that the SMEs owners are most of the time the managers of their business. These business owners were willing to know and learn more on how OSM can gives impact to their businesses from time to time. It began with their responses on the reasons using OSN. The next points are on benchmarking practices; the challenges using this medium nowadays.

\section{A. Reasons in using OSM in the Business}

Business owner 1: Engagement of owners is the best place to share idea about the product they offer. Obviously, online social media can be a tool in promoting some exhibition that company take part. By taking photos, upload and spread it through those platform, it really helps the company. As SME, you must make your company exist in the market along with the establish company and of course to invest in "over the line" marketing is tough because we don't know the acceptance of product in the market. By using online social network, you can make it more specific over online marketing is general, the ads and posters is for everybody. With online social media, you may segment your target consumer such as (which area, range of age, what kind of activity they interest). This is more cost effective."

Business owner 2: "I admit that we are following the trend because most of the people nowadays get the information through their fingertips. Most of people like to read news on internet compared to newspapers and magazine. Our company did not put any advertisement to the newspaper and magazine since online marketing did not use any cost of it. For every one week, I post a status on Facebook about three times but I will respond to the customer question every day. Usually, we search for people who make cookies, cakes from their house without using any machine by using facebook From Facebook, we may find those people."

However, from the above responses the interviewees suggested that OSM plays a big role as a marketing tool due to its cost effectiveness, accessibility, tangibility, reliability and assurance. The OSM characteristics mentioned above assist SME to push their products and services to the unlimited market segmentation. By establishing relations with existing and potential customers, this media opens wide opportunities for SMEs to meet customers' needs and wants.

\section{B. Benchmarking Practices}

Business owner 1: "Yes, we do as a reference for our company. For example, website. There is always an idea whether you want to go for e-commerce line or information line. So you have to look at the reference which one suit your product best. Despite of promoting our product, we also want to promote our own facilities. So we need this kind of promotion to have that balance with benchmarking the company with successful online media. For Facebook account, we follow the company style of post with many likes. We follow how they engage with the consumer. The closest example with Moola is Nature valley, Yogood. I think, Facebook, Twitter, Instagram account are very crucial nowadays because it already been a need to company."

Business owner 2: "Yes, we produce our own product so that it became unique from the others. But, we try to make new customers to buy from us."

The first interviewee managed to practise informal benchmarking through competitors' websites which were established international brand for the same type of product. By analyzing the appearance as well as the outputs displayed, they keen to learn how they came out with the ideas in producing sensation outputs which will encourage more research and development activities. From the interviews, it can be seen that although informal benchmarking activities involved through OSN, it also can becomes as ongoing part of the management process for that respective businesses.

\section{Push and Pull Factors in Using OSM}

Business owner 1: "The push factors are you will know how many people like and communicate on your product. 
And the most important thing is, if you understand the algorithm in Facebook for example, you can create a viral or phenomenon on your product. For every account that you have you need to understand how it function and operate. There is no point if one company only have an online account but did not use it wisely. Moreover, you can instantly build a relationship with the customers because you already have the target segment. When there is communication, there is trust and it will loyalty by this engagement. The last one is you may capture the traffic leads. For example in facebook account, there is 10,000 like. So how you want to convert it to become 1000 customers at least. For the pull factor, you need to provide the "soft sell" in this online social media. It also hard to deal with if one person put too much effort on it because you have to be in front of the laptop. The trainee of the online social media is the one who get more benefit while the company need to practice it without knowing the profit."

Business owner 2: "Positive things inside is we may promote our product to all customers. Our products have its own uniqueness that make customer feel want to buy it. Other than that, we know what customer need is. Other example, we posted a photo of chocolate design into the Facebook but there were people who stole our design and mentioned it as their product. Before this, we don't put any watermark or symbol to our design. But after that, we patented our product.

From the above response, the interviewees commented how OSN influence their decision making that is related to 4Ps as well as promotional effort that had been before [27]. On top of that, these channels allow frequent communication with customers and engagement towards loyalty. This situation urges them to make creative limitless attempts as their rivals in the market [28].

\section{CONCLUSION}

In conclusion, factors such as lack of benchmarking partners, and technical knowledge in planning benchmarking projects can be readily addressed through resources such as books, guides, consultants and benchmarking networks. Technological innovations particularly online applications go hand in hand with more stringent benchmarks for businesses. In fact, new online applications also have the potential to facilitate co-operation and information exchange amongst them. The use of the technique could help redefine standards before they are changed by the closest competitors. Perhaps, more local businesses will be able to move from informal to formal benchmarking exercises regardless the size and type of industries. On the other hand, roles by the third party like SME Corp and Malaysia Productivity Corporation (MPC) as partly regulators are important to implement formal benchmarking among businesses as to avoid anti-competitive behavior. Future studies on these subjects may consider more generalizable results with the use of surveys and cases to validate respective model that would be an expected extension.

\section{ACKNOWLEDGMENT}

The authors would like to thank Universiti Sains Islam Malaysia for the opportunity to carry out this study as well as the business owners who participated in this study.

\section{REFERENCES}

[1] M. Taylor and A. Murphy, "SMEs and e-business," Journal of Small Business and Enterprise Development, vol. 11, no. 3, pp. 280-289, 2004.

[2] D. Jutla, P. Bodorik, and J. Dhaliwal, "E-business readiness of small and medium enterprises," Internet Research: Electronic Networking Applications and Policy, vol. 12, no. 2, pp. 139-164, 2002.

[3] Berita Harian (2012). PKS dijangka terus berkembang 2014. [Online]. Available:

http://www.bharian.com.my/bharian/articles/PKSdijangkaterusberkem bang2014/Article/index_html

[4] A. E. M. Hesham, "Understanding benchmarking in Egyptian organizations: An empirical analysis," Benchmarking: An International Journal, vol. 15, no. 6, pp. 742-764, 2008.

[5] P. Garengo, S. Biazzo, A. Simonetti, and G. Bernardi, "Benchmarking on managerial practices: a tool for SMEs," The TQM Magazine, vol. 17, no. 5, pp. 440-455, 2005.

[6] J. W. Alstete, "Measurement benchmarks or "real" benchmarking? An examination of current perspectives," Benchmarking: An International Journal, vol. 15, no. 2, pp. 178-186, 2008.

[7] L. C. R. Carpinetti and A. M. de Melo, "What to benchmark? A systematic approach and cases," Benchmarking: An International Journal, vol. 9, no. 3, pp. 244-255, 2002.

[8] M. Zairi, "Benchmarking: The best tool for measuring competitiveness," Benchmarking for Quality Management and Technology, vol. 1, no. 1, pp. 11-24, 1994.

[9] M. Gable, A. Fairhurst, and R. Dickinson, "The use of benchmarking to enhance marketing decision making," Journal of Consumer Marketing, vol. 10, no. 1, pp. 52-60, 1993.

[10] O. Kyriakidou and J. Gore, "Learning by example: Benchmarking organizational culture in hospitality, tourism and leisure SMEs," Benchmarking: An International Journal, vol. 12, no. 3, pp. 192-206, 2005.

[11] R. B. McKay and E. Chung, "Benchmarking for entrepreneurial survival: Pursuing a cohesive and imperfectly imitable culture," Benchmarking: An International Journal, vol. 12, no. 3 pp. 207-218, 2005.

[12] D. Adebanjo, A. Ahmed, and R. Mann, "An investigation of the adoption and implementation of benchmarking," International Journal of Operations and Production Management, vol. 30, no. 11, pp. 1140-1169, 2010.

[13] P. Hong, W. H. Soon, R. J. Jungbae, and P. Kihyun, "Evolving benchmarking practices: a review for research perspectives," Benchmarking: An International Journal, vol. 19, no. 4/5, pp. 444-462, 2012.

[14] J. Sarkis, "Benchmarking for agility," Benchmarking: An International Journal, vol. 8, no. 2, pp. 88-107, 2001.

[15] P. L. Yean, Z. Suhaiza, and L. S. Keng, "Understanding factors for benchmarking adoption: New evidence from Malaysia," Benchmarking: An International Journal, vol. 13, no. 5, pp. 548-565, 2006.

[16] T. Fernandez, I. P. McCarthy, and T. R, Joel, "An evolutionary approach to benchmarking," Benchmarking: An International Journal, vol. 8, no. 4, pp. 281-305, 2001.

[17] S. Rothenberg, B. Schenk, and J. Maxwell, "Lessons from benchmarking environmental performance at automobile assembly plants," Benchmarking: An International Journal, vol. 12, no. 1, pp. 5-15, 2005.

[18] W. K. Chung, "Benchmarking Singapore's high-TQM maturity organizations," Benchmarking: An International Journal, vol. 8, no. 1, pp. 8-34, 2001.

[19] C. Cassell, S. Nadin, and M. O. Gray, "The use and effectiveness of benchmarking in SMEs," Benchmarking: An International Journal, vol. 8, no. 3, pp. 212-222, 2001.

[20] R. McAdam and M. Kelly, "A business excellence approach to generic benchmarking in SMEs," Benchmarking: An International Journal, vol. 9, no.1, pp. 7-27, 2002.

[21] A. W. Norailis and A. R. Syarizal, "Areas for benchmarking among SMEs," International Journal of Trade, Economics and Finance, vol. 4, no. 5, pp. 270-273, 2013.

[22] C. Tansley, "What do we mean by the term "talent" in talent management?” Industrial and Commercial Training, vol. 43, no. 5, pp. 266-274, 2011.

[23] R. Dattakumar and R. Jagadeesh, "A review of literature on Benchmarking," Benchmarking: An International Journal, vol. 10, no. 3, pp. 176-209, 2003.

[24] M. Y. Mahmoud, "The theory and practice of benchmarking: Then and now," Benchmarking: An International Journal, vol. 9, no. 3, pp. 217-243, 2002. 
[25] B. B. Lazo, "Benchmarking financial services and online innovations," Benchmarking: An International Journal, vol. 11, no. 5, pp. 431-446, 2004.

[26] L. B. Ru, Y. W. Bin, N. Maguluru, and M. Nichols, "Enhancing business networks using social network based virtual communities, " Industrial Management and Data Systems, vol. 106, no. 1, pp. 121-138, 2004.

[27] H. Park and H. Cho, "Social network online communities," Journal of Consumer Marketing, vol. 29, no. 6, pp. 400-411, 2012.

[28] M. L. Kasavana, K. Nusair, and K. Teodosic, "Online social networking: Redefining the human web," Journal of Hospitality and Tourism Technology, vol. 1, no. 1, pp. 68-82, 2010.

[29] A. Muscio, G. Nardone, and A. Dottore, "Understanding demand for innovation in the food industry," Measuring Business Excellence, vol. 14, no. 4, pp. 35-48, 2010.

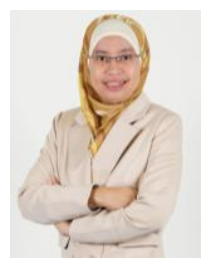

A. W. Norailis is a senior lecturer in the Faculty of Economics and Muamalat, Universiti Sains Islam Malaysia (USIM). She is a member of malaysian Muamalat association (MMA) and The Malaysian consumer and family economics association (MACFEA). She attained her first degree in industrial economics in 2000 and master in science (productivity and quality enhancement) in the following year from
Universiti Kebangsaan Malaysia. In the middle of 2009, she had been awarded PhD from the University of Stirling, Scotland. She joined SME corporation Malaysia (SME Corp) for three months in 2012 through USIM academic staff attachment program to gain industrial experiences and strengthen the networking with practitioners in small and medium enterprises (SMEs). She has published cases on umrah management and organizational issues in "Integrated Muamalat Case Study" published by the Penerbit USIM. Presently, she involves in research on benchmarking, supply chain and umrah management as well as in activities organized by Malaysia Productivity Corporation (MPC) and SME Corp.

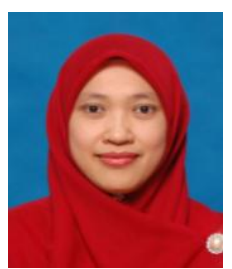

Y. Nor Asiah is a lecturer of accounting at Universit Sains Islam Malaysia (USIM). She obtained her degree in accountancy from Universiti Utara Malaysia and master's degree in information technologymanagement from Universiti Technology Malaysia Prior to joining USIM, she was a lecturer at Universiti Utara Malaysia for seven years. She also an associate member of Malaysia institute of accountants (MIA) 